\title{
Evaluation of physiochemical characteristics of fresh and osmotic dehydrated fig (Ficus carica $L$.)
}

\section{Pandidurai G.*}

Department of Food Science and Nutrition, Community Science College and Research Institute, Tamil Nadu Agricultural University, Coimbatore - 641003 (Tamil Nadu), India

Vennila P.

Department of Post-Harvest Technology Centre, Agricultural Engineering College and Research Institute, Tamil Nadu Agricultural University, Coimbatore - 641003 (Tamil Nadu), India

Amutha S.

Community Science College and Research Institute, Tamil Nadu Agricultural University, Coimbatore - 641003 (Tamil Nadu), India

${ }^{*}$ Corresponding author. Email: nanalpandi@gmail.com

\section{How to Cite}

Pandidurai, G. et al. (2021). Evaluation of physiochemical characteristics of fresh and osmotic dehydrated fig (Ficus carica L.) . Journal of Applied and Natural Science, 13 (SI), 69 - 72. https://doi.org/10.31018/jans.v13iSI.2779

\begin{abstract}
Fig (Fiscus carica L.) fruits being the rich source of phytochemicals, particularly anti-oxidants serve as a powerhouse of nutrients and has many medicinal properties. Fig promoting healthy bowel function due to the high level of fiber. Rich in vitamins $A, C, E$, and minerals like calcium useful to improve the health status and to balance the $\mathrm{pH}$ of the body. Due to its short -lived nature, it cannot be stored for longer period (2-3 days) because higher postharvest losses. The lag in processing of fig is mainly attributed to the highly perishable nature of the fig as it posses high moisture content. The objective of the work was to improve the shelf life and reduce the perishability of fig. Two varieties, namely Local and Timla (Yercud - 1) variety were selected and osmotically dehydrated with different concentration $\left(30,40\right.$ and $50^{\circ}$ brix $)$ of sugar solution. Timla variety contained lower percentage of seeds $(21 \%)$ and fibre $(2.05 \mathrm{~g} / 100 \mathrm{~g})$, higher pulp thickness $(1.0 \mathrm{~cm})$, maximum colour values $(\mathrm{L}-70.30$, $\mathrm{a}-4.65$ and $\mathrm{b}-12.37)$, TSS $\left(19^{\circ} \mathrm{brix}\right)$ and vitamin $\mathrm{C}(39.0 \mathrm{mg} / 100 \mathrm{~g})$ than the local variety. Timla variety treated with $50^{\circ}$ brix osmotic solution was found better nutrient retention, drying characteristics and organoleptic properties. The resultant products had improved shelf life and increased concentration of nutrients, making it suitable for processing and value addition.
\end{abstract}

Keywords: Osmotic- dehydration, Processing, Variety, Value addition, Water loss

\section{INTRODUCTION}

Fig (Fiscus carica L.), a tropical shrub belongs to the family of Moraceae. The origin of fig is Middle East and Western Asia. The fig is grown in tropical and subtropical region of India. Approximately 800 varieties of Figs in the world. The 'Poona' is the most popular cultivar in Karnataka, Tamil Nadu, Maharashtra, Gujarat and Uttar Pradesh. (Lavanya et al., 2018). Figs are delicious and very perishable commodity leads to early senescence, fermentation, and produce quality losses are fungal decay which limit their shelf life during storage at ambient temperature. (Colelli and Amodio, 2020).As Fig possess high amount of moisture content, it is highly perishable. Manual harvesting is done by twisting the pedicel or cutting. Harvest can also be done after the fruits are dropped in the ground. The harvest gap is usually at 2-3 days interval (manually). The harvest yield ranges from 180-360 fruits per tree. Harvesting before optimum maturity results in milky latex exudation which reduces the acceptability of the fig. The shelf life of refrigerated fig ranges about 2-3 days and dried fig ranges about 6-8 months. (Jadhav and Gurav, 2018).

Fig fruit is rich in dietary fiber, minerals like iron, copper and potassium content. The nutritional and nutraceutical rich fruits processing rate is very low which makes it an under-utilized fruit. Hence the need to process fig fruit should be addressed to provide essential nutrients and prevent hidden hunger for the vulnerable popula- 
tion. Hiwale, (2015) Osmotic dehydration is a type of processing of fruits and vegetables for removal of water content by immersing in some concentrated sugar or salt solution, the lower concentration of solute to higher concentration through semi permeable membrane results in the equilibrium condition in both sides of membrane by removal of water. (Chavan and Amarowicz, 2012; Niranjan et al., 2018).

The osmotic dehydration is a simple, cost-effective, non -destructive and energy intensive process with better retention of physico - chemical and organoleptic characteristics viz., aroma, texture, colour and nutritional composition and also preventing the fruit decolouration by enzymatic browning (Niranjan et al., 2018, Sharma et al., 2003). The water activity of osmotically dehydrated food products is lowered, resulting in preventing microbial growth and reducing food spoilage. After osmotic dehydration processes, $50 \%$ of the weight was reduced in food materials that can be used for further processing (easy handling, transport and storage) and value addition to enhance the shelf life and products available throughout the year. (Yadav and Singh , 2014, , Eroglu and Yildiz, 2010).

\section{MATERIALS AND METHODS}

The fig fruit (fresh, firm and ripe) was purchased from local farmers and disinfected in running tap water. Two varieties like local (Small size figs having pink flesh and a deep purple skin that appears black after dried) and timla (Yercud - 1 Timla variety drought tolerant and crimson red fruit Suitable for plains and mid-hills) fig fruits were steam blanched (3-5 $\mathrm{min}$ ) and pre-sterilized for facilitating softening and de-bugging respectively. The fruits were soaked in different concentrations of sugar solution $-30^{\circ}$ brix $\left(T_{1}\right), 40^{\circ}$ brix $\left(T_{2}\right)$, and $50^{\circ}$ brix $\left(\mathrm{T}_{3}\right)$ with $0.5 \% \mathrm{KMS}$ solution for a duration of $24 \mathrm{hrs}$. The soaked fruits were drained free of sugar solution, pressed, dried at $60^{\circ} \mathrm{C}$ in a cabinet drier as per Pandidurai and Vennila (2020). The physio-chemical characteristics of both fresh and osmotically dehydrated fig fruit were analysed by Ranganna (1977).

\section{RESULTS AND DISCUSSION}

The physical characteristics of fig varieties are given in Table 1. The fig fruit local variety possessed individual weight $-38.5 \mathrm{~g}$, diameter $-9.7 \mathrm{~cm}$, brown colour in skin, light pink colour, pulp thickness $-1 \mathrm{~cm}$, seed weight $18.2 \mathrm{~g}$ and colour values $\mathrm{L}, \mathrm{a}, \mathrm{b}-64.18,-1.74,14.30$ respectively. Timla variety fig fruit is reddish-brown in colour, weight of fruit $-69.0 \mathrm{~g}$, diameter of fruit -16.9 $\mathrm{cm}$, pulp colour - pinkish red, pulp thickness $-1.0 \mathrm{~cm}$, seed weight $-14.5 \mathrm{~g}$ and colour values $\mathrm{L}, \mathrm{a}, \mathrm{b}-70.30$, $4.65,12.37$ respectively.

The chemical constituents of the fig fruit variety, such as local and Timla having a moisture content was 78.15 and 79.80 per cent, respectively. The TSS content of fig fruit was $14^{\circ}$ brix in local variety and in Timla variety has $19^{\circ}$ brix. Acidity, $\mathrm{pH}$, and fibre content present in the local variety shows that fruit has a 0.16 per cent, 5.27 , $2.89 \mathrm{~g} / 100 \mathrm{~g}$ and in timla variety has 0.19 per cent, $5.10,2.05 \mathrm{~g} / 100 \mathrm{~g}$ respectively. The fig fruit has a total sugar and reducing sugar content was 12.88 and 6.86 $\mathrm{g} / 100 \mathrm{~g}$ in local variety and 18.04 and 8.35 in Timla variety, respectively. Vitamin $C$ content present in the local variety was $16.8 \mathrm{mg} / 100 \mathrm{~g}$ and Timla variety was 39.0 $\mathrm{mg} / 100 \mathrm{~g}$, shown in Table 2.

Mhalaskar et al. (2012) reported that the chemical parameters of Hisalu (Rubus ellipticus Sm) variety of fig fruits- moisture content $79.2 \%$, total acidity $0.17 \%, \mathrm{pH}$ value 5.3. fig fruit contained $20^{\circ}$ brix total soluble solids, reducing and non-reducing sugar content- $14.98 \%$, $1.70 \%$, respectively.

Khapre et al., 2015 investigation revealed the chemical composition of fig fruits variety (Deanna cultivar). Fresh Deanna cultivar having $22^{\circ}$ brix total soluble solids, 75.3 per cent moisture, 0.23 per cent acidity against 5.4 of $\mathrm{pH}$ value and 1.43 per cent dietary fiber content. They also revealed that reducing sugar 17.43 per cent and non-reducing sugar 2.7 per cent in fig fruit variety. Deanna cultivar contained protein 1.75 per cent, fat 0.52 per cent and ascorbic acid $12.95 \mathrm{mg} / 100 \mathrm{~g}$.

Poona fig variety having delicious in nature and dark

Table 1. Physical characteristics of fig fruit varieties.

\begin{tabular}{|c|c|c|c|}
\hline \multirow{2}{*}{\multicolumn{2}{|c|}{ Particulars }} & \multicolumn{2}{|c|}{ Varieties of fig } \\
\hline & & Local & Timla \\
\hline \multicolumn{2}{|c|}{ Weight of the fruit (g) } & 38.5 & 69.0 \\
\hline \multicolumn{2}{|c|}{ Diameter of the fruit $(\mathrm{cm})$} & 9.7 & 16.9 \\
\hline \multicolumn{2}{|c|}{ Skin colour of the fruit } & Brown & Reddish brown \\
\hline \multicolumn{2}{|c|}{ Pulp colour of the fruit } & Light pink & Pinkish red \\
\hline \multicolumn{2}{|c|}{ Pulp thickness(cm) } & 0.6 & 1.0 \\
\hline \multicolumn{2}{|c|}{ Seed weight(g) } & $18.2(47 \%)$ & $14.5(21 \%)$ \\
\hline \multirow[t]{3}{*}{ Colour values } & L & 64.18 & 70.30 \\
\hline & a & -1.74 & -4.65 \\
\hline & $b$ & 14.30 & 12.37 \\
\hline
\end{tabular}

Table 2. Chemical characteristics for fig fruits.

\begin{tabular}{lll}
\hline \multirow{2}{*}{ Particulars } & \multicolumn{2}{c}{ Varieties of fig } \\
\cline { 2 - 3 } & Local & Timla \\
\hline Moisture (\%) & 78.15 & 79.80 \\
TSS ('brix) & 14 & 19 \\
Acidity (\%) & 0.16 & 0.19 \\
$\mathrm{pH}$ & 5.27 & 5.10 \\
Total sugars (g/100g) & 12.88 & 18.04 \\
Reducing sugars $(\mathrm{g} / 100 \mathrm{~g})$ & 6.86 & 8.35 \\
Fibre $(\mathrm{g} / 100 \mathrm{~g})$ & 2.89 & 2.05 \\
Vitamin C (mg/100g) & 16.8 & 39.0 \\
Water activity (aw) & 0.93 & 0.94 \\
\hline
\end{tabular}


Table 3. Drying characteristics of osmotic dehydrated fig fruit.

\begin{tabular}{|c|c|c|c|c|c|}
\hline \multirow{2}{*}{ Particulars } & & \multicolumn{4}{|c|}{ Variations } \\
\hline & & $T_{0}$ & $T_{1}$ & $T_{2}$ & $T_{3}$ \\
\hline Time taken for drying (hrs.) & & 18 & 20 & 21 & 23 \\
\hline Percentage recovery & & 28.0 & 34.0 & 40.0 & 49.0 \\
\hline Moisture content (\%) & & 6.19 & 6.30 & 8.95 & 9.47 \\
\hline \multirow[t]{2}{*}{ Water activity (aw ) } & & 0.613 & 0.638 & 0.715 & 0.744 \\
\hline & $\mathrm{L}$ & 67.77 & 70.55 & 71.79 & 7.41 \\
\hline \multirow[t]{2}{*}{ Colour values } & a & 2.09 & 0.79 & -1.50 & -1.44 \\
\hline & $b$ & 14.72 & 13.87 & 13.03 & 12.83 \\
\hline Hardness $(\mathrm{N})$ & & 84 & 60 & 54 & 46 \\
\hline
\end{tabular}

$T_{0}$ - Control , $T_{1}-30^{\circ}$ brix, $T_{2}-40^{\circ}$ brix and $T_{3}-50^{\circ}$ brix

purple to green in colour. It contained moisture content $(79.11 \mathrm{~g} / 100 \mathrm{~g})$, protein $(0.75 \mathrm{~g} / 100 \mathrm{~g})$, total fat $(0.30 \mathrm{~g} / 100 \mathrm{~g})$, ascorbic acid $(2.0 \mathrm{mg} / 100 \mathrm{~g})$, sugar $(16.26 \mathrm{~g} / 100 \mathrm{~g})$ and dietary fiber $(2.9 \mathrm{~g} / 100 \mathrm{~g})$ reported by (Arvaniti et al., 2019)

From the physico-chemical characteristics, Timla variety possessed lower percentage of seeds and fibre than the local variety, higher pulp thickness, maximum colour values, TSS, sugars and vitamin $C$ than the local variety. Hence for the processing of osmotic dehydration Timla variety was selected for further study.

\section{Drying characteristics of osmatic dehydrated fig fruit}

The drying characteristics such as time taken for drying, percentage recovery, moisture content, water activity, colour values and hardness of the fig are given in Table 3. The results found that the concentration of sugar syrup increased and the time taken for drying was also increased. The control $\left(T_{0}\right)$ had taken a minimum time of $18 \mathrm{hrs}$ and the sample treated with $50^{\circ}$ brix $\left(T_{3}\right)$ osmotic solution had taken a maximum time of $23 \mathrm{hrs}$ for drying. Similar to drying time, the percentage recovery was greater in higher concentrated osmotic solution ( $28 \%$ to $49.0 \%$ ). The moisture content and water activity of the samples ranged from $6.19 \%$ to $9.47 \%$ and 0.613 to $0.744 \mathrm{a}_{\mathrm{w}}$ respectively in $\mathrm{T}_{0}, \mathrm{~T}_{1}, \mathrm{~T}_{2}$ and $\mathrm{T}_{3}$.

Lavanya et al. (2018) did experiments on osmotic dehydration of Fig fruit slices using different sugar solution concentrations. Finally, they observed that maximum water loss was observed at $50^{\circ}$ brix concentration (20.72\%) when compared to $40^{\circ}$ brix $(12.26 \%)$ and $30^{\circ}$ brix $(7.64 \%)$. The weight reduction in tray drying after 4 $\mathrm{hr}$ the drying rate was gradually decreased and till reached a constant weight. They concluded that the quality of osmotic dehydrated Fig fruit slices was best at $50^{\circ}$ brix of sugar concentration.

The colour values of dehydrated fig fruits showed that $\mathrm{T}_{3}$ retained maximum values than the other treatments. The hardness of the dehydrated fig fruits done by the texture analyzer indicated that as the concentration of sugar syrup increased, the hardness of the dehydrated fig fruit was decreased. Organoleptic characteristics of the dehydrated fig fruit done by 9-1 hedonic scale showed that maximum score values were in the sample treated with $50^{\circ}$ brix $\left(T_{3}\right)$. A similar result was found that osmotic dehydrated bedu variety (Ficus palmate) of fig fruit, the brix increases $\left(40^{\circ} \mathrm{Brix}, 50^{\circ} \mathrm{Brix}\right.$ and $60^{\circ}$ Brix) the moisture content was decreased with respect to processing time and temperature but the amount of moisture loss decreases depending upon the soaking time. They finally revealed that fig fruit treated with $40^{\circ}$ Brix sugar solution dried at $60^{\circ} \mathrm{C}$ for 8 hrs by using a tray dryer having better retention of nutritional composition and sensory properties by Niranjan et al. (2018).

The chemical parameters for osmatic dehydrated fig fruits (Table 4) having moisture - 9.47 per cent, TSS $80.4^{\circ}$ brix, acidity -0.11 percent, $\mathrm{pH}-5.40$, total sugar - $76.04 \mathrm{~g} / 100 \mathrm{~g}$, reducing sugar $-4.29 \mathrm{~g} / 100 \mathrm{~g}$, fibre $5.94 \mathrm{~g} / 100 \mathrm{~g}$, ash - $5.94 \mathrm{~g} / 100 \mathrm{~g}$, vitamin C - 10.97 $\mathrm{mg} / 100 \mathrm{~g}$, antioxidant $-109.34 \mathrm{mg} / \mathrm{g}$, water activity -

Table 4. Chemical characteristics of osmotic dehydrated fig fruit.

\begin{tabular}{|c|c|c|}
\hline Particulars & & Dehydrated fig \\
\hline Moisture (\%) & & 9.47 \\
\hline TSS(॰ brix) & & 80.4 \\
\hline Acidity (\%) & & 0.11 \\
\hline $\mathrm{pH}$ & & 5.40 \\
\hline Total sugars(g/100g) & & 76.04 \\
\hline Reducing sugars $(\mathrm{g} / 100 \mathrm{~g})$ & & 4.29 \\
\hline Fibre $(g / 100 g)$ & & 5.94 \\
\hline Ash(g/100g) & & 1.93 \\
\hline Vitamin C(mg/100g) & & 10.97 \\
\hline Antioxidant(mg/g) & & 109.34 \\
\hline Water activity(aw) & & 0.744 \\
\hline \multirow{3}{*}{ Colour values } & L & 75.41 \\
\hline & a & -1.50 \\
\hline & b & 15.04 \\
\hline
\end{tabular}


0.744 and colour value Lab 75.41, - 1.50 and 15.04 respectively.

Bellary fig variety treated with osmotic sugar solution showed 13.75 per cent of maximum weight reduction, 23.52 per cent of dried fruit recovery, minimum 83.70 hours for dehydration and also recorded maximum colour values $L^{*}$ (40.15), $a^{*}$ (9.06) and $b^{*}$ (19.05) and sensory characteristics (Bharathkumar et al., 2018). Naikwadi et al. (2010) earlier reported that fresh dehydrated dinkar fig variety showed excellent organoleptic characteristics for fructose sugar syrup and invert sugar syrup treatments for colour and appearance, texture, taste and overall acceptability and also dried figs contained about $19 \%$ moisture in $55^{\circ}$ brix.

\section{Conclusion}

The fig fruits treated with $50^{\circ}$ brix osmotic solution were the best treatment for drying characteristics and sensory evaluation. The formulated food products from osmotically dehydrated fig fruit in different products provided a value addition for the fruit with nutritional quality. The products will reach Technology Research Level 5 (TRL-5) for commercialization by meeting all regulatory compliance requirements. . The products are costeffective from both production and consumption point of view. There is a massive scope for plausibility to make the product available throughout the year, which helps the farmers demand side remains stable with profitable farmgate prices.

\section{Conflict of interest}

The authors declare that they have no conflict of interest.

\section{REFERENCES}

1. Arvaniti, O. S., Samaras, Y., Gatidou, G., Thomaidis, N. S., \& Stasinakis, A. S. (2019). Review on fresh and dried figs: Chemical analysis and occurrence of phytochemical compounds, antioxidant capacity and health effects. Food Research International, 119, 244-267. DOI: 10.1016/ j.foodres.2019.01.055.

2. Bharathkumar, A., Jagadeesh, S. L., Netravati, V. H., Bhuvaneshwari, G., \& Bindu, H. (2018). A study on fruit preparation on quality of fig fruits (cv. Bellary) osmoticdehydrated under solar tunnel dryer. Journal of Pharmacognosy and Phytochemistry, 7(3), 3177-3180

3. Chavan, U. D. \& Amarowicz, R. (2012). Osmotic dehydra- tion process for preservation of fruits and vegetables. Journal of Food Research, 1(2), 202. DOI: 10.5539/ jfr.v1n2p202

4. Colelli, G., \& Amodio, M. L. (2020). Subtropical fruits: Figs. In: Controlled and Modified Atmospheres for Fresh and Fresh-Cut Produce (pp. 427-434). Academic Press. DOI:10.1016/b978-0-12-804599-2.00030-2

5. Eroglu, E., \& Yildiz, H. (2010). Recent developments in osmotic dehydration. Akademik Gıda, 8(6), 24-28.

6. Hiwale, S. (2015). Fig (Ficus carica) In: Sustainable Horticulture in Semiarid Dry Lands (pp. 159-175). Springer, New Delhi. DOI: 10.1007/978-81-322-2244-6_11.

7. Jadhav, P. B., \& Gurav, N. P. (2018). Extension of storage and post-storage shelf-life of fig fruit. International Journal of Research and Review, 5(3), 25-34.

8. Khapre, A. P., Satwadhar, P. N., \& Deshpande, H. W. (2015). Studies on standardization of fig fruit (Ficus carica L.) powder enriched cookies and its composition. Asian Journal of Dairy \& Food Research. 7 (2), 621 - 624.

9. Lavanya, K, Upendar K, Adamala sirisha \& Bandhu S. (2018). Osmotic Dehydration Process for preservation of fig fruit and its quality evaluation. International Journal of Agriculture Sciences, 10(3), 5099-5101. DOI: 10.9735/0 975-3710.10.3.5099-5101

10. Mhalaskar, S. R., Lande, S. B., Satwadhar, P. N., Deshpande, H. W., \& Babar, K. P. (2012). Development of technology for fortificatin of fig (Ficus carica L.) fruit into its value added product-fig toffee. International Journal of Processing and Post Harvest Technology, 3(2), 176-179

11. Naikwadi, P. M., Chavan, U. D., Pawar, V. D., \& Amarowicz, R. (2010). Studies on dehydration of figs using different sugar syrup treatments. Journal of Food Science and Technology, 47(4), 442-445. DOI: 10.1007/s13197010-0073-6

12. Niranjan, T., Rajender, G., Reddy, P., Reddy, V., Kumar, A., \& Krishna, V. (2018). Study on osmotic dehydration of fig fruit (Ficus carica) slices mediated tray drying. International Journal of Current Microbiology and Applied Sciences, 7(6), 3198-3205. DOI 10.20546/ijcmas.201 8.70 6.375.

13. Pandidurai, G. \& Vennila, P. (2020) Processing, value addition and effect of nutritional quality of fig fruit by osmatic dehydration. International Journal of Chemical Studies, 8(4):3644-3647. DOI: https://doi.org/10.22271/chem i.202 0.v8.i4at.10213.

14. Ranganna, S. (1977). Manual of Analysis Fruits and Vegetables. Tara-McGraw Hill, New Delhi, 1-3.

15. Sharma, H. K., Pandey, H., \& Kumar, P. (2003). Osmotic dehydration of sliced pears. The Journal of Agricultural Engineering, 40(1), 65-68.

16. Yadav, A. K., \& Singh, S. V. (2014). Osmotic dehydration of fruits and vegetables: a review. Journal of Food Science and Technology, 51(9), 1654-1673. DOI: 10.1007/ s13197-012-0659-2. 